\title{
Pengembangan Sistem Informasi PERISAI (Pelaporan Mandiri saat Isolasi) untuk Orang Dalam Pemantauan Covid-19
}

\author{
Eriyanto Adhi Setyawan \\ Sekolah Teknik Elektro dan Informatika \\ Institut Teknologi Bandung \\ Bandung, Indonesia \\ eri.setyawan@students.itb.ac.id \\ Asmawi Tri Prabowo \\ Sekolah Teknik Elektro dan Informatika \\ Institut Teknologi Bandung \\ Bandung, Indonesia \\ awie_22_milano@students.itb.ac.id
}

\author{
Silvia \\ Sekolah Teknik Elektro dan Informatika \\ Institut Teknologi Bandung \\ Bandung, Indonesia \\ chil_jj@students.itb.ac.id \\ Hafidz Adnan \\ Sekolah Teknik Elektro dan Informatika \\ Institut Teknologi Bandung \\ Bandung, Indonesia \\ hafidz.adnan@students.its.ac.id \\ Bayu Setyawan \\ Sekolah Teknik Elektro dan Informatika \\ Institut Teknologi Bandung \\ Bandung, Indonesia \\ bayu.setyawan@students.itb.ac.id
}

\author{
Ninon Nurul Faiza \\ Sekolah Teknik Elektro dan Informatika \\ Institut Teknologi Bandung \\ Bandung, Indonesia \\ ninon.nurulfaiza@students.itb.ac.id \\ Nia Semartiana \\ Sekolah Teknik Elektro dan Informatika \\ Institut Teknologi Bandung \\ Bandung, Indonesia \\ nia.semartiana@students.itb.ac.id
}

\begin{abstract}
Abstrak - Salah satu langkah pencegahan penyebaran virus COVID-19 dapat dilakukan dengan cara melakukan karantina terhadap kelompok orang berisiko diantaranya ODP (Orang Dalam Pemantauan) selama 14 hari dan surveilans/pemantauan kondisi kesehatan ODP tersebut selama masa karantina sebagaimana panduan yang diterbitkan Kementrian Kesehatan Indonesia berupa Kartu Kewaspadaan Kesehatan Pedoman dan Pencegahan Pengendalian COVID-19. Upaya karantina/isolasi mandiri dilakukan sebagai metoda untuk membatasi seseorang atau sekelompok orang dalam suatu wilayah yang diduga terinfeksi penyakit dan/atau terkontaminasi. Namun pemantauan terhadap kepatuhan pelaksanaan isolasi mandiri sulit dilakukan karena puskesmas sebagai unit fasilitas kesehatan yang ditugaskan untuk melakukan pemantauan tidak memiliki alat pantau yang dapat menjamin kepatuhan ODP selama masa isolasi. PERISAI merupakan sistem informasi yang bertujuan untuk mendukung pemantauan ODP yang dapat dilaksanakan secara merata diseluruh daerah terutama bagi penduduk yang baru tiba setelah melakukan perjalanan dari daerah yang memiliki riwayat transmisi lokal COVID-19 dengan konsep digitisasi Kartu Kewaspadaan Kesehatan. PERISAI dikembangkan terbatas pada pengelolaan informasi ODP yang dapat digunakan oleh puskesmas dibawah naungan dinas kesehatan di lingkungan Kabupaten/Kota. Dengan demikian, petugas puskesmas dapat memonitoring proses isolasi mandiri yang dilakukan oleh ODP melalui aplikasi web dan ODP juga dapat melaporkan kondisi kesehatannya secara berkala melalui aplikasi mobile. Sistem informasi PERISAI dikembangkan menggunakan model pengembangan protoyping yang menghasilkan beberapa modul sistem yaitu web aplikasi, mobile aplikasi serta REST API sebagai alat komunikasi sistem.
\end{abstract}

Keywords - transformasi digital, pemantauan, covid-19.

\section{Pendahuluan}

Pada tanggal 30 Januari 2020, WHO menetapkan COVID-19 sebagai Public Health Emergency of International Concern (PHEIC)/ Kedaruratan Kesehatan Masyarakat Yang Meresahkan Dunia (KKMMD)[1]. Hal ini juga diperkuat dengan terbitnya Keppres 11 tahun 2020 tentang Penetapan Kedaruratan Kesehatan Masyarakat COVID-19 dan Peraturan Pemerintah Republik Indonesia Nomor 21 Tahun 2020 tentang Pembatasan Sosial Berskala Besar Dalam Rangka Percepatan Penanganan Corona Virus Disease 2019 (COVID-19) sebagai pedoman penanggulangan konfirmasi kasus COVID-19 yang terus bertambah di Indonesia.

Berdasarkan penjelasan pedoman penanggulangan konfirmasi kasus COVID-19 [2], tanda dan gejala umum infeksi COVID-19 antara lain gejala gangguan pernapasan akut seperti demam, batuk dan sesak napas. Masa inkubasi rata-rata 5-6 hari dengan masa inkubasi terpanjang 14 hari. Pada kasus COVID-19 yang berat dapat menyebabkan pneumonia, sindrom pernapasan akut, gagal ginjal, dan bahkan kematian.

CAsosiasi Prakarsa Indonesia Cerdas (APIC) - 2020 
Tanda-tanda dan gejala klinis yang dilaporkan pada sebagian besar kasus adalah demam, dengan beberapa kasus mengalami kesulitan bernapas, dan hasil rontgen menunjukkan infiltrat pneumonia luas di kedua paru. Berdasarkan bukti ilmiah, COVID-19 dapat menular dari manusia ke manusia melalui percikan batuk/bersin (droplet), namun tidak melalui udara. Orang yang paling berisiko tertular penyakit ini adalah orang yang kontak erat dengan pasien COVID-19 termasuk yang merawat pasien COVID-19. Rekomendasi standard untuk mencegah penyebaran infeksi adalah melalui cuci tangan secara teratur menggunakan sabun dan air bersih, menerapkan etika batuk dan bersin, menghindari kontak secara langsung dengan ternak dan hewan liar serta menghindari kontak dekat dengan siapapun yang menunjukkan gejala penyakit pernapasan seperti batuk dan bersin serta menerapkan protokol Pencegahan dan Pengendalian Infeksi (PPI) saat berada di fasilitas kesehatan terutama unit gawat darurat.

Salah satu protokol untuk melaksanakan pencegahan dan pengendalian COVID-19 di Indonesia adalah melakukan upaya surveilans/pemantauan yang berlangsung terus menerus terhadap kelompok berisiko. Selain itu, upaya karantina juga perlu dilakuan sebagai metoda pembatasan seseorang atau sekelompok orang dalam suatu wilayah termasuk wilayah yang diduga terinfeksi penyakit dan/atau terkontaminasi untuk mencegah kemungkinan penyebaran penyakit atau kontaminasi. Kegiatan surveilans merupakan bagian tidak terpisahkan dari karantina [2]. Selama masa karantina, pelaksanaan surveilans dilakukan untuk memantau perubahan kondisi seseorang atau sekelompok orang berisiko dianataranya adalah ODP (Orang Dalam Pemantauan).

Kegiatan surveilans terhadap ODP dilakukan berkala untuk mengevaluasi adanya perburukan gejala selama 14 hari. Petugas kesehatan dapat melakukan pemantauan melalui telepon atau melalui kunjungan secara berkala (harian) dan dicatat pada formulir pemantauan harian. Pemantauan dilakukan dalam bentuk pemeriksaan suhu tubuh dan skrining gejala harian. Pemantauan dilakukan oleh petugas kesehatan layanan primer dan berkoordinasi dengan dinas kesehatan setempat. Orang dalam pemantauan yang sudah dinyatakan sehat yang tidak memiliki gejala terkait COVID-19, ditetapkan melalui surat pernyataan yang diberikan oleh dinas kesehatan melalui puskesmas setempat.

Walaupun kegiatan pemantauan terhadap ODP wajib dilakukan, namun faktanya pemantauan atas kepatuhan pelaksanaan isolasi mandiri sulit dilakukan karena puskesmas tidak mempunyai alat untuk melakukan engagement terhadap ODP selama masa isolasi. Kementerian Kesehatan telah menerbitkan Pedoman dan Pencegahan Pengendalian COVID-19 dengan Kartu Kewaspadaan Kesehatan sebagai panduan pelaksanaan isolasi mandiri serta memudahkan monitoring isolasi mandiri yang dilakukan oleh ODP. Namun, hal tersebut belum dapat dilaksanakan secara merata di seluruh daerah di Indonesia terutama bagi penduduk yang baru tiba melakukan perjalanan dari daerah yang memiliki riwayat transmisi lokal COVID-19. Selain itu, penduduk berstatus ODP seringkali tidak menghiraukan himbauan isolasi mandiri selama 14 hari akibat tidak adanya monitoring terhadap ODP tersebut. Oleh karena itu pertanyaan dalam pengembangan ini adalah Bagaimana merancang suatu sistem Informasi yang dapat memutus mata rantai penyebaran virus COVID-19 melalui karantina dan surveillance terhadap kelompok berisiko, khususnya ODP secara terpadu dan berkelanjutan sesuai dengan standard pemantauan pada Kartu Kewaspadaan Kesehatan.

Pengembangan sistem informasi PERISAI bertujuan untuk menawarkan digitisasi Kartu Kewaspadaan Kesehatan yang dikeluarkan oleh Kementerian Kesehatan sebagai panduan pelaksanaan isolasi mandiri serta memudahkan monitoring isolasi mandiri yang dilakukan oleh ODP. Sistem ini dibangun sebagai pendukung proses pemantauan ODP yang belum dapat dilaksanakan secara merata di seluruh daerah terutama bagi penduduk yang baru tiba melakukan perjalanan dari daerah yang memiliki riwayat transmisi lokal COVID-19. Pembangunan sistem PERISAI juga terbatas pada informasi ODP yang dapat digunakan oleh Puskesmas di bawah naungan dinas Kesehatan di lingkungan Kabupaten/Kota.

CAsosiasi Prakarsa Indonesia Cerdas (APIC) - 2020 


\section{LANDASAN TEORI}

Menjelaskan beberapa kajian penelitian terkait yang dapat mendukung pengembangan Sistem Informasi PERISAI khususnya pada metode pengenalan lokasi dan justifikasi kondisi kesehatan.

\section{A. Transformasi Digital}

Revolusi industri 4.0 memacu penerapan transformasi digital guna mengintegrasikan Teknologi Informasi dan Komunikasi (TIK) ke dalam kegiatan perusahaan untuk meningkatkan kinerja, membangun interaksi dengan pelanggan, dan menciptakan nilai baru dalam rangka menjaga kemampuan bersaing perusahaan [3]. Demikian juga pada sektor publik, transformasi digital direspons pemerintah dengan melakukan perubahan layanan pemerintahan melalui pemanfaatan teknologi digital agar lebih mudah diakses, efektif dan akuntabel. Bentuk transformasi digital layanan pemerintah tersebut dapat kita lihat dalam penyelenggaraan e-government [4]. Dengan e-government dapat meningkatkan efisiensi layanan publik, terutama untuk selalu memenuhi kebutuhan baru masyarakat yang terus bertambah [5]. Menurut Amancio [6], bentuk transformasi digital terbagi menjadi tiga, yaitu:

\section{1) Digitization}

mengacu pada pembuatan digital representasi objek fisik (Contoh: scanning kertas menjadi bentuk PDF)

\section{2) Digitalization}

mengacu pada mengaktifkan, meningkatkan atau mentransformasikan bisnis proses dengan memanfaatkan teknologi digital dan data digital. (Contoh: penggunaan API untuk komunikasi layanan antar modul sistem)

\section{3) Digital Transformation}

melakukan perubahan kegiatan bisnis, kompetensi, dan model bisnis untuk sepenuhnya memanfaatkan peluang digital teknologi. (Contoh: verifikasi otomatis profil pelanggan sebagaimana database guna target pemasaran yang efektif)

\section{B. Teknologi Persuasif}

Kehadiran internet telah menyebabkan penyebaran situs web yang dapat dirancang untuk memotivasi perubahan sikap dan perilaku seseorang secara persuasif. Berbagai contoh situs web yang menerapkan teknologi persuasif dan umum digunakan untuk saat ini seperti: (1) Amazon, (2) Facebook, (3) e-Bay, dan lain-lain. Selain situs web, teknologi persuasif juga diterapkan dalam berbagai bentuk, mulai dari ponsel pintar hingga sistem komputerisasi sebuah trailer yang dapat memantau kecepatan mobil dalam upaya untuk meyakinkan pengemudi agar mematuhi batas kecepatan. Dalam beberapa kasus, teknologi persuasif bahkan mungkin tidak terlihat oleh penggunanya. Dengan munculnya komputasi tertanam (embedded computing), bentuk-bentuk teknologi persuasif kemungkinan akan menjadi lebih beragam, "tidak terlihat," dan lebih terintegrasi ke dalam kehidupan sehari-hari. Sehingga, situs web yang sangat menonjol saat ini hanyalah salah satu dari banyak bentuk teknologi persuasif dalam 10 tahun ke depan.

Penggunaan teknologi persuasif akan terus berkembang dalam beberapa tahun mendatang. Berbagai tempat dapat menjadi sarana penerapan yang tepat untuk teknologi ini. Di tempat kerja misalnya, teknologi persuasif dapat digunakan untuk memotivasi pegawai dalam menetapkan tujuan dan memenuhi target dan tenggat waktu. Di rumah, teknologi ini dapat mendorong anak-anak untuk mengembangkan kebiasaan belajar yang lebih baik. Sedangkan dalam kehidupan bermasyarakat, teknologi itu juga dapat dimanfaatkan dalam proses pemilihan secara elektronik. Oleh karena itu, teknologi interaktif yang membutuhkan persuasi dapat diterapkan dalam banyak kegiatan sehari-hari.

Menurut Fogg [7], studi terkait penggunaan komputer sebagai teknologi persuasif masih relatif baru. Dalam teknologi persuasif terdapat akronim "captology" manusia berdasarkan pada frase "komputer sebagai teknologi persuasif". Captology berkaitan dengan proses peralihan dari komunikasi yang dimediasi computer (berfokus pada kebutuhan manusia) menjadi komputer manusia interaksi (mampu mempengaruhi manusia). Dengan kata lain, captology berfokus pada desain, penelitian, dan analisis produk komputasi interaktif yang dibuat untuk tujuan mengubah sikap atau perilaku orang. Gambar.1

CAsosiasi Prakarsa Indonesia Cerdas (APIC) - 2020 
akan mendeskripsikan hubungan antara sumber daya komputasi dengan captology pada teknologi persuasif.

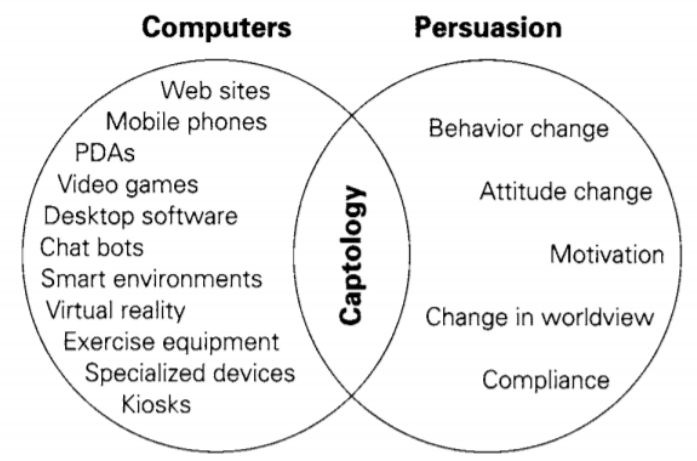

Gambar.1 Hubungan teknologi persuasif dengan sumber daya komputasi

Teknologi persuasif terbagi menjadi beberapa jenis, yaitu:

1) Reduction

Sistem yang dapat membujuk pengguna melalui penyederhanaan dan mengurangi aktivitas kompleks menjadi beberapa langkah sederhana (one-click solution). Contoh: fitur beli langsung pada Tokopedia.

2) Tunneling

Sistem yang dapat memaksa pengguna untuk berkomitmen dalam setiap proses yang harus dilalui. Contoh: Aplikasi diet

3) Tailoring

Sistem yang menyediakan informasi yang relevan dan telah disesuaikan bagi seseorang. Contoh: pemantau kemacetan pada Waze.

4) Suggestion

Sistem yang dapat melakukan "campur tangan" atau intervensi pada waktu yang tepat. Contoh: limiter batas kecepatan pada bus antar kota.

5) Self-monitoring

Teknologi yang dapat memantau aktivitas diri sendiri dengan mengukur dan melacak kinerja atau status tertentu dalam rangka memodifikasi sikap atau perilaku mereka untuk mencapai tujuan atau hasil yang telah ditentukan. Contoh: jam tangan pintar.

6) Surveillance

Teknologi komputasi yang memungkinkan satu pihak dapat memantau perilaku orang lain, sehingga dapat memberikan saran untuk memodifikasi perilaku dengan cara tertentu. Contoh: penggunaan Imoo AutoWatch, yang memungkinkan orang tua untuk memantau aktivitas anak-anak mereka.

Dunkin Donut menambahkan.

7) Conditioning

Sistem terkomputerisasi yang menggunakan prinsip pengkondisian untuk memperkuat alas an perubahan perilaku seseorang.

Contoh: gamifikasi, menerapkan pemberian hukuman dan hadiah.

\section{Situs Web}

Situs web adalah suatu sistem yang berkaitan dengan dokumen digunakan sebagai media untuk menampilkan teks, gambar, multimedia dan lainnya pada jaringan internet [8]. Seiring dengan ketergantungan masyarakat terhadap internet, situs web sebagai aplikasi yang memiliki pengaruh signifikan pada semua aspek kehidupan seperti bisnis, pendidikan, pemerintah, sektor hiburan, industri, hingga kehidupan pribadi. Keuntungan utama mengadopsi web adalah untuk mengembangkan produk perangkat lunak yang handal, meliputi: (1) akses tanpa biaya instalasi, (2) peningkatan kemampuan

CAsosiasi Prakarsa Indonesia Cerdas (APIC) - 2020 
otomatisasi dengan fitur baru untuk semua pengguna, (3) akses universal dari mesin apa pun yang terhubung ke internet, dan (4) tidak tergantung pada sistem operasi klien [9].

\section{Pengumpulan Data berbasis Mobile Crowdsourcing}

Menurut Kong dkk. [10], Mobile Crowdsourcing (MCS) dikenal sebagai sebuah paradigma kunci yang dapat memungkinkan Smart City untuk mengintegrasikan kebijakan kerumunan dinamis dengan memanfaatkan perangkat seluler untuk menyediakan layanan dan aplikasi di mana saja yang terdesentralisasi. Dengan MCS, masyarakat memainkan peran aktif untuk menghasilkan banyak data crowdsourced sehingga dapat secara signifikan meningkatkan pengembangan Smart City. Kemampuan MCS telah direalisasikan sejak perangkat seluler dilengkapi dengan berbagai jenis sensor, seperti kamera, mikrofon, global positioning system (GPS), akselerometer dan lain-lain. Karakteristik utama dari MCS adalah sebagai berikut:

\section{1) Mobilitity}

Smartphone mencerminkan pola mobilitas dan interaksi sosial dari penggunanya. Jadi, mobilitasnya informasi perangkat dapat digunakan untuk meningkatkan kinerja MCS.

\section{2) Collaboration}

MCS memungkinkan pembagian tugas kepada pengguna yang memenuhi syarat dalam kerumunan kerja. Dengan cara ini, pengguna smartphone dapat berkolaborasi dalam melaksanakan serangkaian tugas untuk mencapai tujuan.

\section{3) Human Capacity}

Individu atau pengguna smartphone memainkan peran sebagai konsumen dan produsen data dalam MCS, yaitu ketika kapasitas penginderaan, komunikasi, dan pemrosesan yang mereka lakukan digunakan untuk meningkatkan kinerja sistem MCS.

\section{Metode Pengembangan}

Sistem Informasi PERISAI dibangun menggunakan metode pengembangan prototyping sebagai model proses yang berdiri sendiri untuk membantu memahami model sistem yang harus dibangun ketika persyaratan tidak dijelaskan secara detail, dalam kasus ini hanya berdasarkan informasi pada Kartu Kewaspadaan Kesehatan yang dikeluarkan oleh Kementerian Kesehatan. Paradigma prototyping dimulai dengan komunikasi dengan mempelajari Kartu Kewaspadaan Kesehatan sebagai mekanisme untuk mengidentifikasi persyaratan perangkat lunak.

Model prototyping dilakukan secara berurutan dan berulang/beriterasi yang mendukung perencanaan prototipe dengan cepat guna menyajikan pemodelan atas desain cepat tersebut. Desain cepat tidak berfokus pada representasi aspek-aspek perangkat lunak yang akan terlihat oleh pengguna akhir (misalnya. tata letak antarmuka manusia atau format tampilan keluaran). Namun, mengarah pada pembangunan prototipe yang dapat segera digunakan dan dievaluasi oleh para pemangku kepentingan, kemudian segera memberikan umpan balik yang digunakan untuk menyempurnakan perangkat lunak. Proses iterasi metode prototyping dapat dilihat pada Gambar.2.

CAsosiasi Prakarsa Indonesia Cerdas (APIC) - 2020 


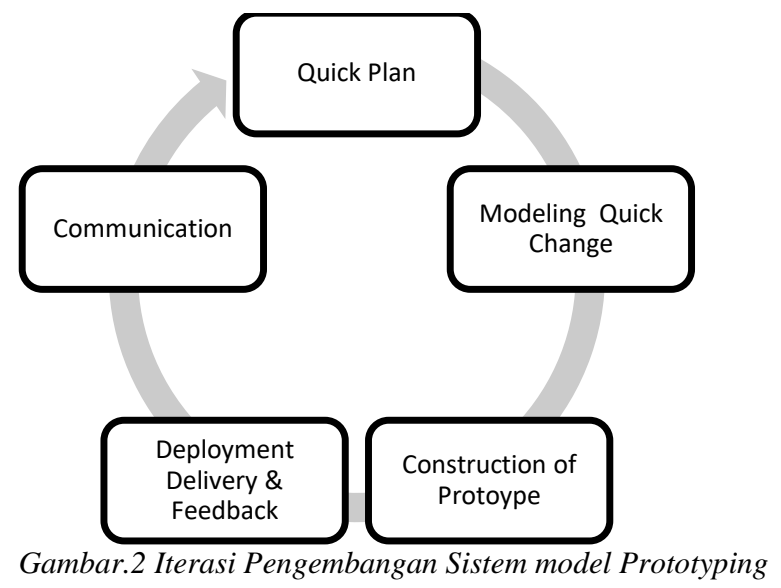

Mekanisme prototyping memungkinkan prototipe perlahan berevolusi menjadi sistem yang sebenarnya dan diterima untuk digunakan oleh pemangku kepentingan sehingga dapat menjadi paradigma yang efektif untuk rekayasa perangkat lunak. Kuncinya adalah menekankan semua pemangku kepentingan harus setuju bahwa prototipe dibangun untuk berfungsi sebagai mekanisme untuk mendefinisikan persyaratan dan perlahan berkembang untuk mencapai kualitas yang diinginkan [11].

Tahapan pengembangan yang dilakukan berdasarkan metode prototyping untuk membangun sistem informasi PERISAI dapat dijelaskan pada Tabel.1.

Tabel.1 Tahapan Pengembangan Sistem PERISAI

\begin{tabular}{|c|c|c|c|c|}
\hline No & Tahapan & Input & Aktivitas & Output \\
\hline 1 & Quick plan & $\begin{array}{l}\text { Peraturan, pedoman } \\
\text { dan protocol } \\
\text { penanganan ODP dari } \\
\text { pemerintah }\end{array}$ & $\begin{array}{l}\text { Mengidentifikasi } \\
\text { bisnis }\end{array}$ & $\begin{array}{l}\text { Hasil analisis proses bisnis } \\
\text { penanganan ODP }\end{array}$ \\
\hline 2 & $\begin{array}{l}\text { Modelling } \\
\text { quick change }\end{array}$ & $\begin{array}{l}\text { Hasil analisis proses } \\
\text { bisnis penanganan } \\
\text { ODP }\end{array}$ & $\begin{array}{lr}\text { Merumuskan } & \text { kebutuhan } \\
\text { fungsional } & \text { sistem } \\
\text { berdasarkan } & \end{array}$ & $\begin{array}{l}\text { Daftar kebutuhan fungsional } \\
\text { sistem yang akan dibangun }\end{array}$ \\
\hline 3 & $\begin{array}{l}\text { Construction of } \\
\text { Prototype }\end{array}$ & $\begin{array}{l}\text { Daftar kebutuhan } \\
\text { fungsional }\end{array}$ & Melakukan coding prototype & Prototype sistem \\
\hline 4 & $\begin{array}{l}\text { Deployment } \\
\text { Delivery \& } \\
\text { Feedback }\end{array}$ & Prototype sistem & $\begin{array}{l}\text { Mempresentasikan prototype } \\
\text { kepada pengguna dan } \\
\text { memperbaiki hasil anlisis } \\
\text { prototype sistem }\end{array}$ & $\begin{array}{l}\text { Daftar perbaikan untuk } \\
\text { pengembangan selanjutnya }\end{array}$ \\
\hline 5 & Communication & Artefak sistem & $\begin{array}{l}\text { Mernyusun dan } \\
\text { mengkomunikassikan setiap } \\
\text { tahapan pengembangan }\end{array}$ & Dokumentasi sistem \\
\hline
\end{tabular}

\section{Pengembangan Sistem}

Penelitian ini akan menganalisis proses pencatatan dan pengawasan terhadap ODP yang merupakan pendatang dari wilayah yang diyakini terjangkit COVID-19 sesuai dengan protokol kesehatan yang dituangkan Kartu Kewaspadaan Kesehatan. Selanjutnya, peranan teknologi informasi diharapkan dapat membantu mewujudkan digital transformasi dari kegiatan tersebut.

\section{A. Analisis Sistem}

Pada pedoman penanganan COVID-19 yang diterbitkan oleh Kementerian Kesehatan Republik Indonesia, menyebutkan bahwa kegiatan surveilans terhadap ODP dilakukan berkala untuk mengevaluasi adanya perburukan gejala selama 14 hari. Petugas kesehatan dapat melakukan pemantauan melalui telepon atau melalui kunjungan secara berkala (harian) dan dicatat pada formulir pemantauan harian.

(C)Asosiasi Prakarsa Indonesia Cerdas (APIC) - 2020 
Pemantauan dilakukan dalam bentuk pemeriksaan suhu tubuh dan skrining gejala harian. Pemantauan dilakukan oleh petugas kesehatan layanan primer dan berkoordinasi dengan dinas kesehatan setempat. Orang dalam pemantauan yang sudah dinyatakan sehat yang tidak memiliki gejala terkait COVID-19, ditetapkan melalui surat pernyataan yang diberikan oleh dinas kesehatan melalui Puskesmas setempat.

Walaupun kegiatan pemantauan terhadap ODP wajib dilakukan, namun faktanya pemantauan atas kepatuhan pelaksanaan isolasi mandiri sulit dilakukan karena Puskesmas tidak mempunyai alat untuk melakukan engagement terhadap ODP selama masa isolasi. Kementerian Kesehatan telah menerbitkan Pedoman dan Pencegahan Pengendalian COVID-19 dengan Kartu Kewaspadaan Kesehatan sebagai panduan pelaksanaan isolasi mandiri serta memudahkan monitoring isolasi mandiri yang dilakukan oleh ODP. Namun, hal tersebut belum dapat dilaksanakan secara merata di seluruh daerah di Indonesia terutama bagi penduduk yang baru tiba melakukan perjalanan dari daerah yang memiliki riwayat transmisi lokal COVID -19. Selain itu, penduduk berstatus ODP seringkali tidak menghiraukan himbauan isolasi mandiri selama 14 hari akibat tidak adanya monitoring terhadap ODP tersebut. Oleh karena itu pertanyaan dalam pengembangan ini adalah Bagaimana merancang suatu sistem Informasi yang dapat memutus mata rantai penyebaran virus Covid-19 melalui karantina dan surveilans terhadap kelompok berisiko, khususnya ODP secara terpadu dan berkelanjutan sesuai dengan standard pemantauan pada Kartu Kewaspadaan Kesehatan.

Berdasarkan hasil dari identifikasi masalah diusulkan suatu solusi yaitu pengembangan sistem informasi PERISAI bertujuan untuk menawarkan digitisasi Kartu Kewaspadaan Kesehatan yang dikeluarkan oleh Kementerian Kesehatan sebagai panduan pelaksanaan isolasi mandiri serta memudahkan monitoring isolasi mandiri yang dilakukan oleh ODP. Sistem ini dibangun sebagai pendukung proses pemantauan ODP (Pedoman dan Pencegahan Pengendalian COVID-19) yang belum dapat dilaksanakan secara merata di seluruh daerah terutama bagi penduduk yang baru tiba melakukan perjalanan dari daerah yang memiliki riwayat transmisi lokal COVID -19. Pembangunan sistem PERISAI juga terbatas pada informasi ODP yang dapat digunakan oleh puskesmas di bawah naungan dinas kesehatan di lingkungan Kabupaten/Kota.

PERISAI menggunakan data yang di inputkan ODP melalui mobile apps sesuai dengan standar Kartu Kewaspadaan Kesehatan yang dikeluarkan Kemenkes. Selama 14 hari masa isolasi mandiri, ODP dapat melakukan pelaporan kesehatan melaui aplikasi jika terjadi perubahan kondisi kesehatan. Berdasarkan data tersebut, Puskesmas dapat memonitoring ODP baik secara kondisi kesehatan maupun kepatuhannya terhadap peraturan isolasi mandiri. Seandainya ODP tidak mematuhi aturan isolasi mandiri yang dideteksi melalui GPS atas pergerakan ODP maka notifikasi akibat pergerakan tersebut akan dikirimkan pada Puskesmas yang mengawasi dan notifikasi peringatan juga terkirim pada mobile phone ODP

\section{B. Proses Bisnis PERISAI}

Sistem Informasi PERISAI digunakan sebagai alat pendukung proses pemantauan ODP yang dilakukan oleh puskesmas di bawah naungan dinas kesehatan di lingkungan Kabupaten/Kota. Adapun proses bisnis yang dilakukan PERISAI dalam mengawasi ODP dapat dijelaskan sebagaimana Gambar.3 berikut ini.

CAsosiasi Prakarsa Indonesia Cerdas (APIC) - 2020 


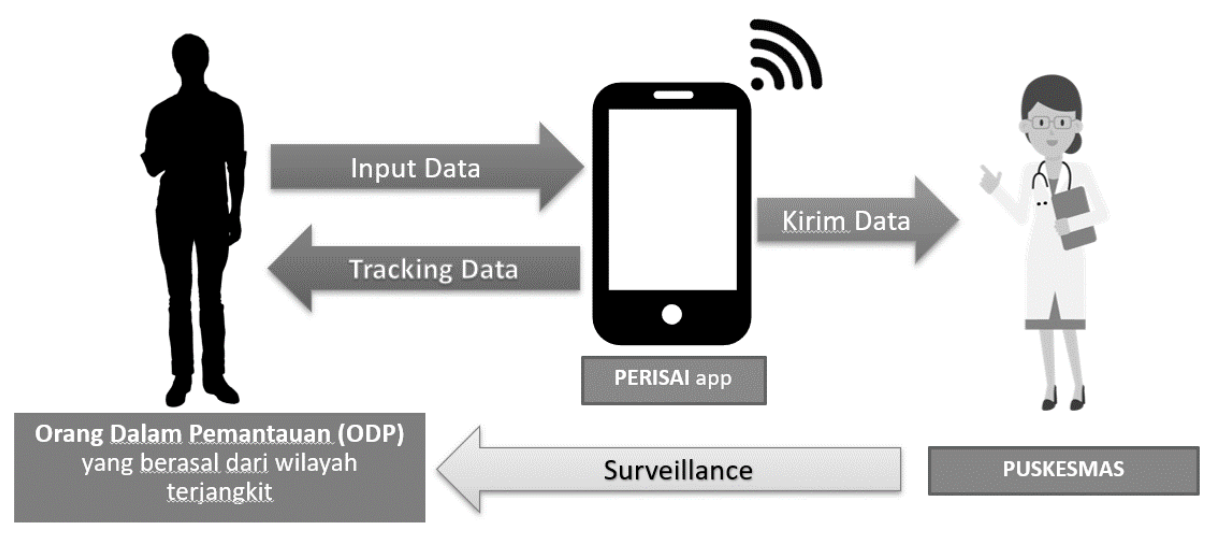

Gambar.3 Alur Proses Bisnis PERISAI

1) Bagi penduduk yang menjadi ODP baru karena telah melakukan perjalanan dari daerah yang memiliki riwayat transmisi lokal COVID-19, wajib melaporkan diri ke fasilitas kesehatan setempat dengan menginstall aplikasi PERISAI mobile.

2) Data yang diinput ODP akan diolah sistem untuk menentukan Puskesmas yang menjadi supervisor dalam melakukan pemantauan. Setelah itu, ODP menuju rumahnya untuk melakukan isolasi diri sementara sistem melakukan tracking posisi ODP berdasarkan rumah untuk melakukan isolasi secara periodik dan mengirimkan data hasil pemantauan kepada Puskesmas terkait.

3) Data-data yang diterima oleh puskemas dapat menjadi dasar untuk menindaklanjuti proses pengawasan ODP. Seperti, puskesmas dapat mengetahui apabila ODP melakukan pelanggaran dengan keluar dari wilayah isolasi atau tidak menyampaikan kondisi kesehatan tanpa perlu melakuakan pengamatan langsung ke rumah-rumah.

4) Setelah masa isolasi selesai, maka Puskesmas dapat menentukan status ODP yang diawasi apakah dinyatakan selesai masa karantina atau lanjut ke status PDP (Pasien dalam Perawatan).

\section{Fitur Sistem}

Sistem Informasi PERISAI terbagi menjadi dua bagian yang masing-masing ditujukan untuk kepentingan spesifik dapat dijelaskan sebagai berikut:

1) PERISAI mobile

Digunakan oleh ODP untuk memudahkan pelaporan kondisi kesehatan selama melakukan isolasi mandiri yang meliputi:

a) Pendeteksian pergerakan/ tracking secara nyaris real time

b) Menyediakan penyampaian pelaporan kondisi kesehatan kepada Puskesmas terdekat

c) Menyediakan informasi terkini terkait status pemantauan kondisi kesehatan yang telah dilakukan oleh Puskesmas

2) PERISAI web

Digunakan oleh Puskesmas untuk memudahkan pemantauan pelaksanaan isolasi mandiri serta kondisi kesehatan ODP selama melakukan isolasi mandiri yang meliputi:

a) Informasi pelanggaran pelaksanaan isolasi mandiri melalui pendeteksian pergerakan ODP secara nyaris real time

b) Menyediakan informasi kondisi kesehatan seluruh ODP yang berada di bawah pemantauan Puskesmas

c) Menyediakan sistem penentuan status ODP setelah masa isolasi selesai untuk dapat ditindaklanjuti ke tahap berikutnya seusai pedoman penanganan dari Kemenkes.

CAsosiasi Prakarsa Indonesia Cerdas (APIC) - 2020 
3) PERISAI API

Digunakan untuk developer untuk mengambil informasi dan data yang telah dikumpulkan pada sistem informasi PERISAI dengan mengadopsi konsep Web Service. Adapun layanan API yang disajikan pada PERISAI meliputi:

a) Otorisasi dan otentifikasi, mengelola akses pengguna layanan API

b) Tracking, mengelola data hasil pendeteksian lokasi ODP selama masa karantina

c) Dinas Kesehatan, mengelola referensi dinas Kesehatan Kabupaten/Kota

d) Area, mengelola referensi Kabupaten/Kota

e) Person, mengelola profil ODP

f) Travel, mengelola histori perjalanan ODP sebelum masa isolasi mandiri

g) Fasilitas Kesehatan, mengelola referensi puskesmas dan rumah sakit pemantau ODP

h) Diagnose, mengelola histori kondisi Kesehatan ODP selama masa isolasi mandiri.

\section{Arsitektur Sistem}

Sistem Informasi PERISAI merupakan layanan yang dapat diakses secara terbuka melalui internet. Masing-masing komponen sistem pada PERISAI dapat berkomunikasi baik antar modul aplikasi maupun dengan sistem eksternal melalui web service. Dengan demikian, PERISAI merupakan sistem informasi yang disusun atas komponen-komponen pengembangan yang dituangkan dalam arsitektur sistem sebagaimana dapat dilihat pada Gambar.4.

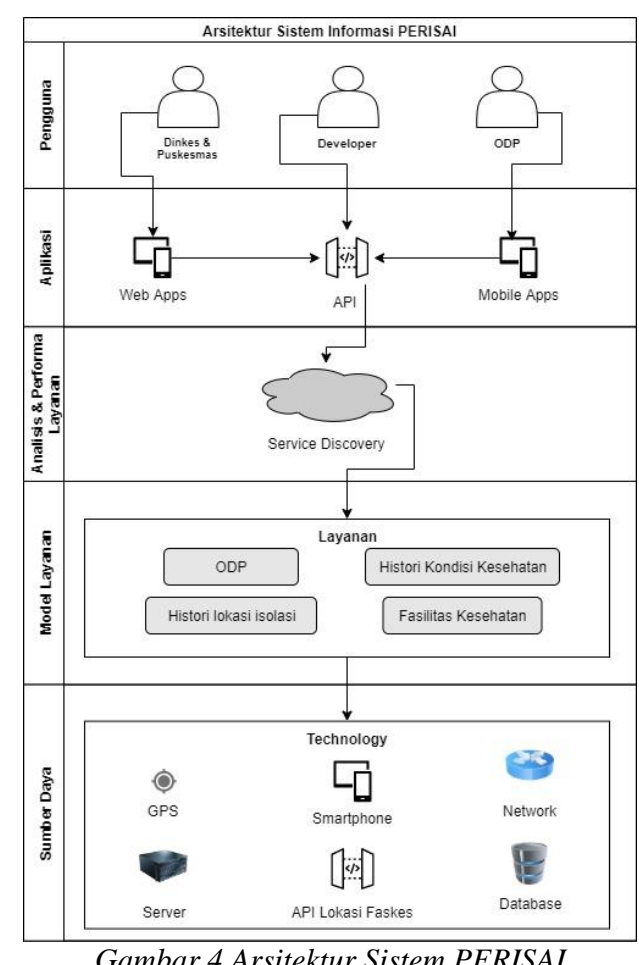

Gambar.4 Arsitektur Sistem PERISAI

\section{Pembahasan}

Menjelaskan hasil pengembangan Sistem Informasi PERISAI yang telah dilakukan khsusnya pada masing-masing modul sistem yang dikembangkan.

CAsosiasi Prakarsa Indonesia Cerdas (APIC) - 2020 


\section{A. PERISAI Mobile}

PERISAI Mobile merupakan aplikasi berbasis android yang akan digunakan untuk melakukan input data ODP yang telah disesuaikan dengan Kartu Kewaspadaan Kesehatan yang digunakan oleh Kementerian Kesehatan. Disamping itu, aplikasi ini akan melakukan pemantauan kepatuhan masa isolasi mandiri yang dilakukan ODP selama 14 hari. ODP akan diminta untuk melakukan registrasi menggunakan akun Google Mail yang telah terdaftar pada smartphone tersebut. Kemudian, ODP akan mengisi data identitas diri, riwayat perjalanan dan kondisi kesehatan saat ini. Aplikasi ini memiliki kemampuan tracking lokasi ODP dengan memanfaatkan sensor GPS yang terdapat pada smartphone ODP tersebut. Selama 14 hari ODP diwajibkan melaporkan kondisi kesehatannya secara rutin melalui aplikasi. Jika masa isolasi mandiri selama 14 hari telah selesai dilakukan, akan muncul pilihan menyelesaikan masa isolasi mandiri untuk menghentikan kewajiban pelaporan kondisi kesehatan dan sistem tracking yang dilakukan oleh aplikasi PERISAI Mobile dengan tampilan sebagaimana dilihat pada Gambar.5.

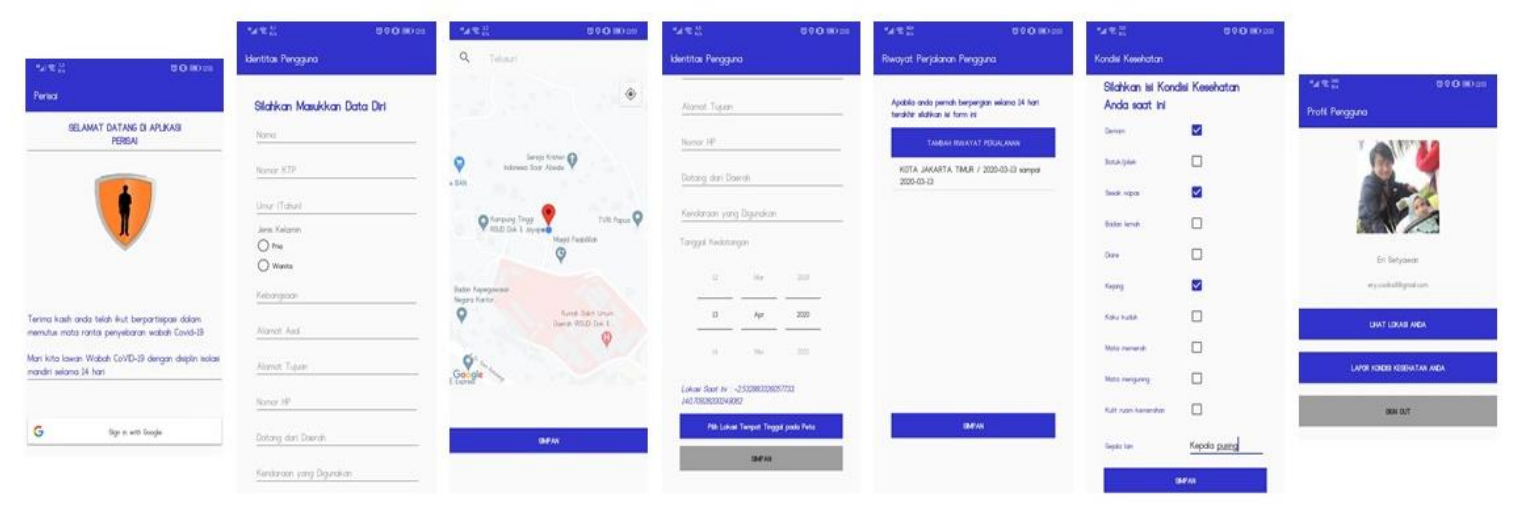

Gambar.5 Tampilan mobile apps PERISAI

PERISAI Mobile mempunyai beberapa fitur utama yang dapat dijelaskan sebagai berikut:

1) Input Data ODP

Setelah menginstall aplikasi PERISAI Mobile, ODP wajib melakukan registrasi dengan akun Google Mail dan mengisikan data identitas diri serta melakukan tagging lokasi tempat tinggal yang akan menjadi lokasi isolasi mandiri. Kemudian, ODP dapat melengkapi data riwayat perjalanan dan kondisi kesehatannya saat ini. Hal tersebut cukup dilakukan satu kali pada saat tahap registrasi.

2) Penentuan Fasilitas Kesehatan (Puskesmas)

Berdasarkan hasil tagging lokasi yang dilakukan pada tahap registrasi, ODP akan memperoleh informasi fasilitas kesehatan yang akan menangani ODP tersebut dengan mempertimbangkan kota/kabupaten dari lokasi tagging berada dan mencari fasilitas kesehatan terdekat yang ada pada kota/kabupaten tersebut. Rekomendasi fasilitas kesehatan diperoleh dengan mengakses PERISAI API yang memiliki data seluruh fasilitas kesehatan di Indonesia beserta titik koordinat lokasinya.

3) Proses Tracking

Aplikasi ini akan berjalan pada background process untuk melakukan tracking posisi ODP setiap menit untuk memastikan bahwa ODP tersebut patuh selama masa isolasi mandiri. Threshold pengguna yang ditetapkan pada aplikasi PERISAI Mobile ditentukan sebagai berikut:

$$
\text { Threshold }=\text { Distance }- \text { Accuracy }
$$

Keterangan:

CAsosiasi Prakarsa Indonesia Cerdas (APIC) - 2020 
Threshold : Jarak minimum antara lokasi saat ini dengan lokasi isolasi mandiri (meter)

Distance : Jarak antara lokasi saat ini dengan lokasi isolasi mandiri berdasarkan titik koordinat (meter)

Accuracy : Jumlah akurasi GPS saat awal melakukan tagging lokasi isolasi mandiri dan akurasi GPS saat ini (meter)

Jika aplikasi mendeteksi threshold pengguna bernilai lebih dari 0 meter, aplikasi akan secara otomatis memberikan pesan notifikasi pada smartphone bahwa ODP tersebut terdeteksi telah berada di luar lokasi isolasi mandiri. Selain itu, aplikasi akan mengirimkan laporan tersebut ke server untuk menjadi informasi yang berguna bagi fasilitas kesehatan yang menangani ODP tersebut.

4) Input Kondisi Kesehatan

Jika tahap registrasi telah selesai, fitur yang disediakan untuk ODP tersebut adalah untuk melaporkan kondisi kesehatannya secara rutin setiap harinya. Laporan tersebut akan dipantau oleh fasilitas kesehatan yang menangani ODP tersebut melalui aplikasi PERISAI Web.

\section{B. PERISAI Web}

PERISAI Web merupakan aplikasi yang akan digunakan untuk memantau kondisi, pergerakan, dan sejarah perjalanan, serta status akhir ODP. Pengguna aplikasi ini terdiri dari 2 level, yaitu: level dinas kesehatan (dinkes) dan level fasilitas kesehatan (faskes). Secara struktur organisasi, terdapat perbedaan diantara kedua level pengguna, yaitu pengguna dengan level dinkes memiliki wewenang untuk mengelola faskes, sedangkan faskes memiliki wewenang yang lebih detil terhadap ODP seperti memperbaharui status kesehatan ODP. Selain itu, ODP yang dapat dipantau oleh pengguna level dinkes adalah seluruh ODP yang ada di wilayah di kabupaten/kota yang menjadi wilayah pemantauan dinas kesehatan di tempat, sedangkan pengguna level faskes hanya dapat memantau ODP yang terdaftar pada fasilitas kesehatan masing-masing. Aplikasi ini menyediakan 4 (empat) menu utama, yaitu Dashboard, Profil, Faskes, dan ODP. Khusus untuk kewenangan pada level Dinkes dapat mengakses Menu Faskes yang digunakan untuk mendaftarkan faskes dan membuat akun pengguna level faskes. Adapun tampilan website PERISAI dapat dilihat pada Gambar.6.

CAsosiasi Prakarsa Indonesia Cerdas (APIC) - 2020 

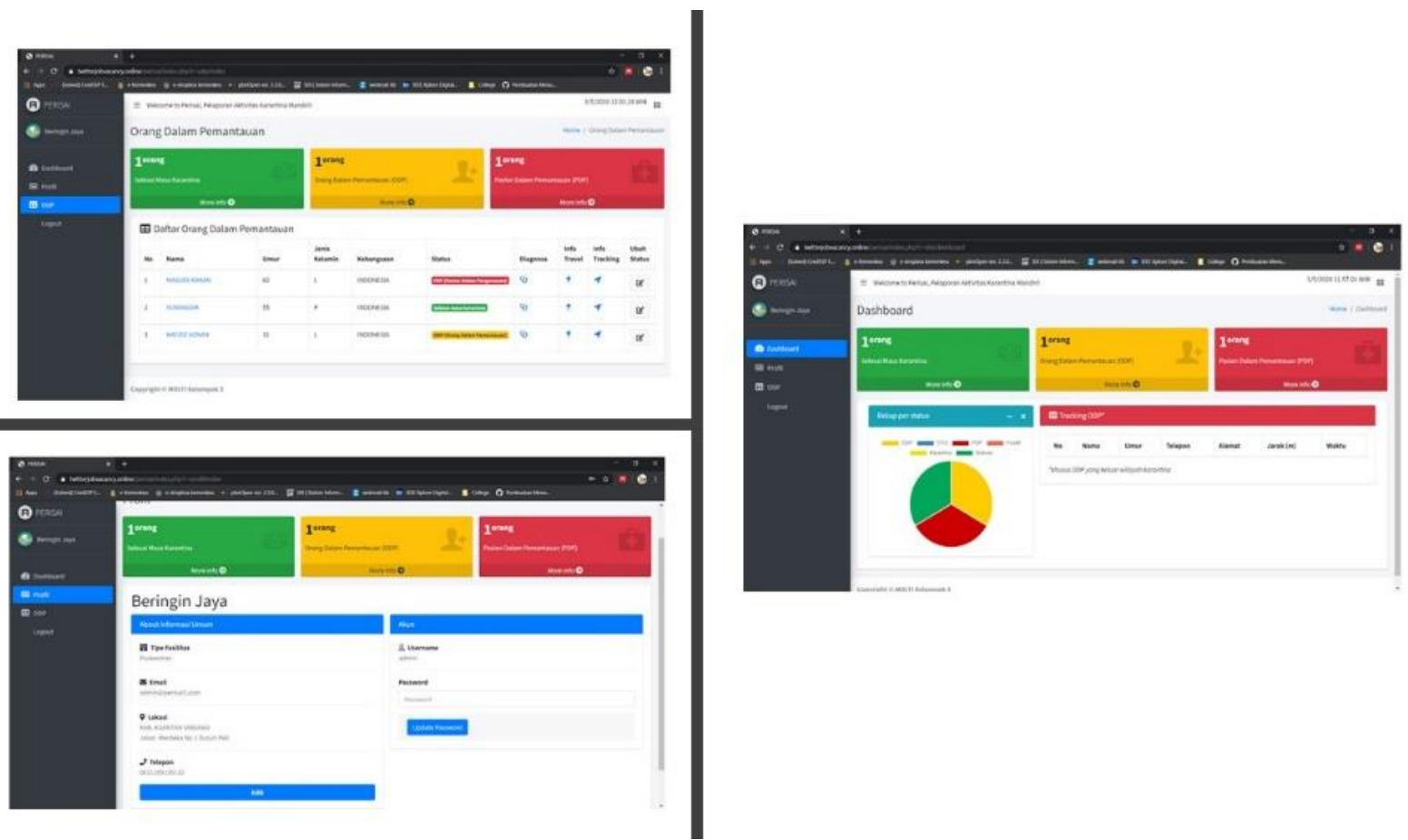

Gambar.6 Tampilan web apps PERISAI

\section{1) Dashboard Monitoring ODP}

Menu ini menampilkan rekap per status dan tracking ODP. Rekap per status menampilkan jumlah ODP, OTG (orang tanpa gejala), PDP (pasien dalam pemantauan), orang yang berstatus positif Covid19, orang dalam karantina, serta orang yang dinyatakan selesai masa status ODP dan dinyatakan negatif Covid-19. Sedangkan tracking ODP menampilkan ringkasan tracking ODP yang keluar dari wilayah karantina selama masa karantina sebagaimana terlihat pada Gambar.7.

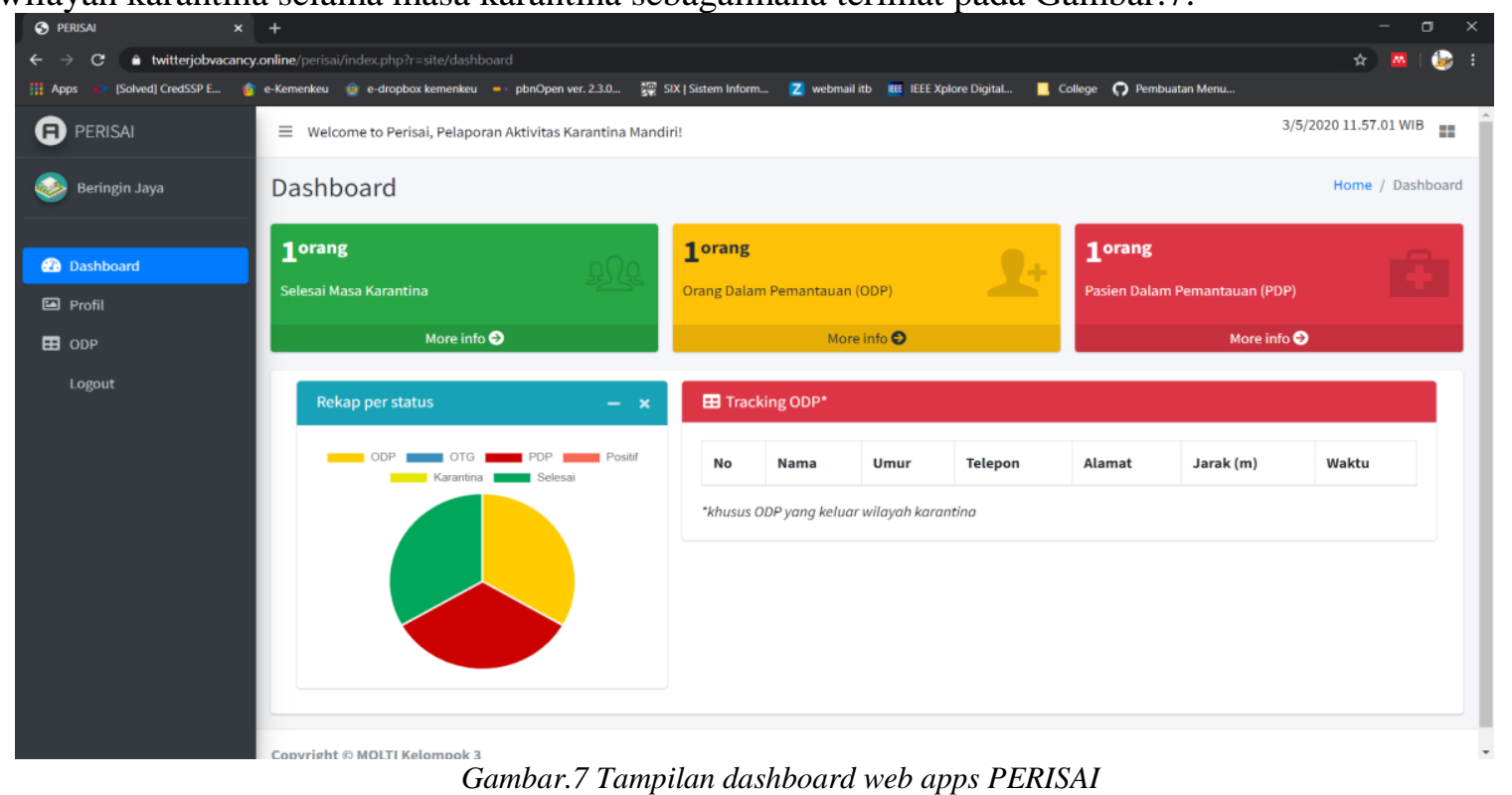

CAsosiasi Prakarsa Indonesia Cerdas (APIC) - 2020 


\section{2) Monitoring $O D P$}

Menu ini menampilkan daftar Orang Dalam Pemantauan (ODP) yang telah mengisi formulir pada Perisai Mobile sebagai pengganti kartu kuning. Seperti diketahui sebelumnya pada aplikasi ini terdapat 2 level user. Apabila login sebagai dinkes maka akan ditampilkan daftar ODP yang ada di setiap faskes yang berada di wilayah pemantauan dinkes tersebut, sedangkan apabila login sebagai faskes maka daftar ODP yang ditampilkan hanya yang berada di wilayah pemantauan faskes tersebut. Pada sistem ini, wilayah pemantauan faskes ditentukan berdasarkan kedekatan jarak bukan berdasarkan wilayah administratif tempat tinggal ODP sebagaimana Gambar.8.

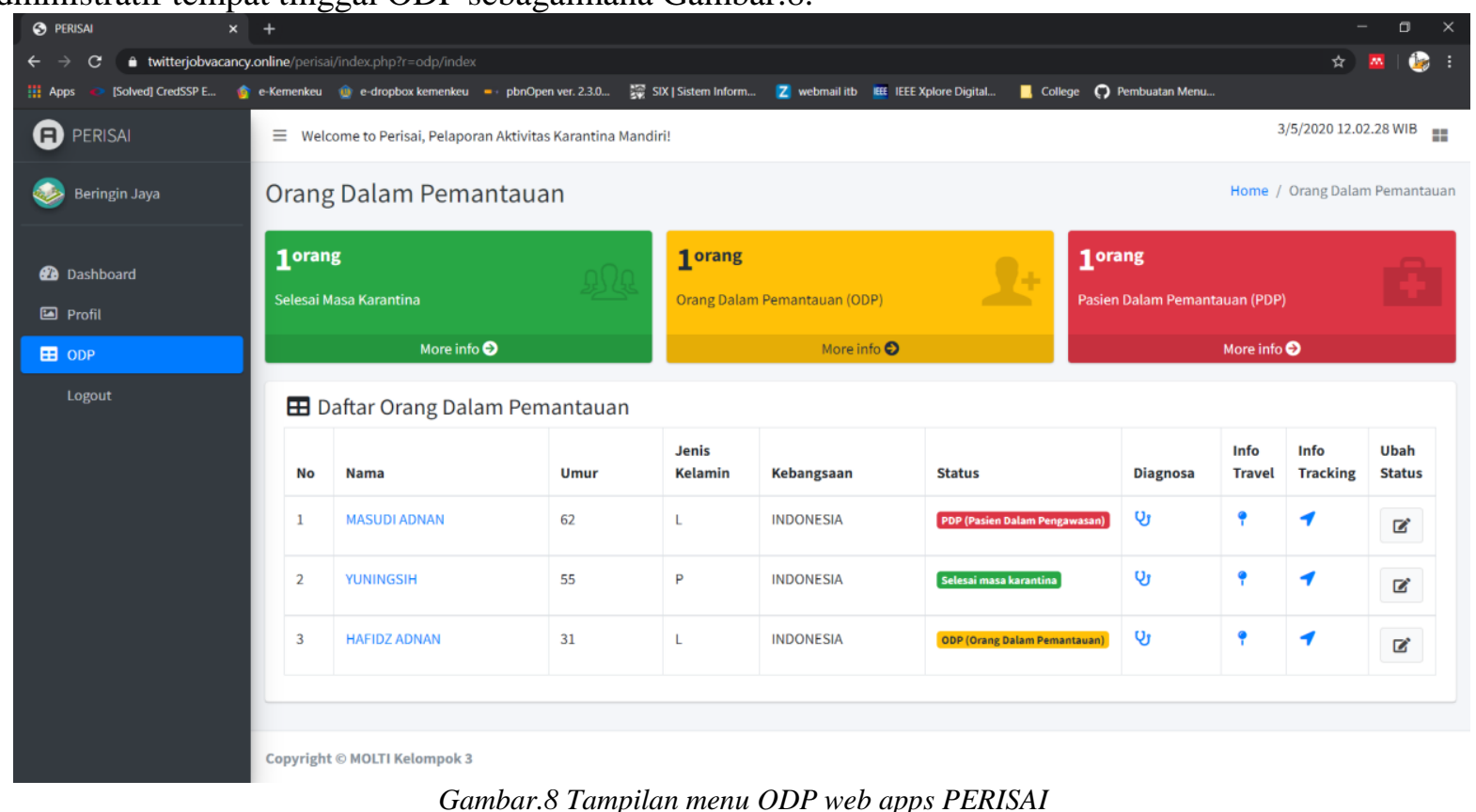

Gambar.8 Tampilan menu ODP web apps PERISAI

Pada masing-masing daftar ODP ini petugas dapat melihat lebih detail data profil dari ODP dengan mengklik bagian namanya sehingga akan tampil informasi lebih detail mengenai ODP tersebut yang dapat dilihat seperti Gambar.9.

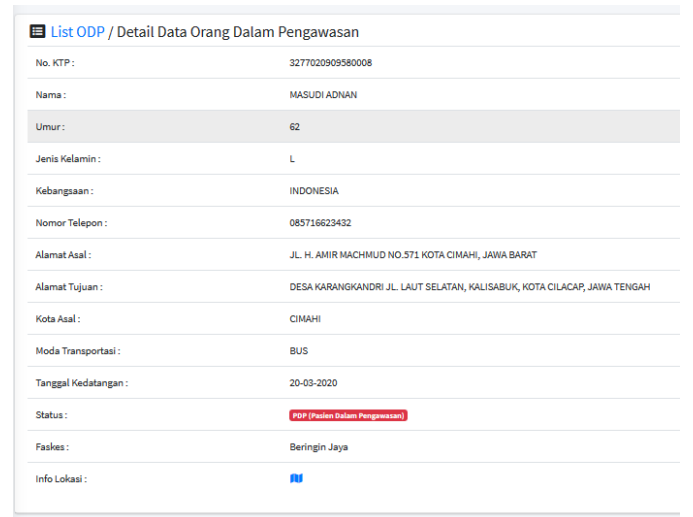

Gambar.9 Tampilan detail profil ODP

Selanjutnya apabila mengklik icon pada info lokasi maka akan menampilkan posisi rumah ODP pada peta. Seperti ditunjukkan pada Gambar.10.

CAsosiasi Prakarsa Indonesia Cerdas (APIC) - 2020 


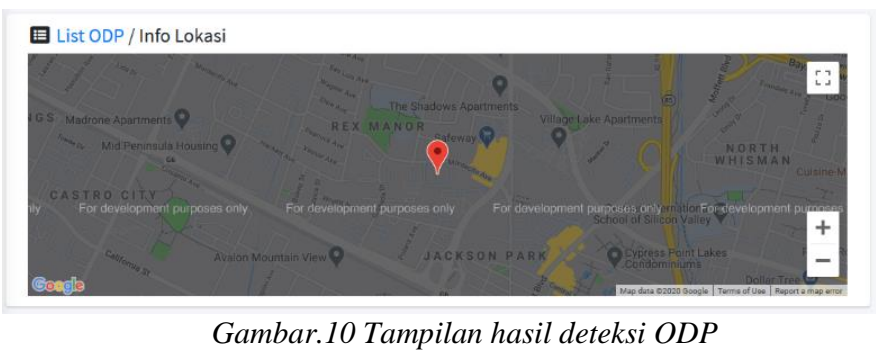

Pada tampilan daftar ODP apabila petugas mengklik icon ${ }^{\text {Uj }}$ pada kolom diagnosa, maka akan menampilkan history diagnosa yang wajib diinput oleh odp selama masa karantina seperti Gambar.11.

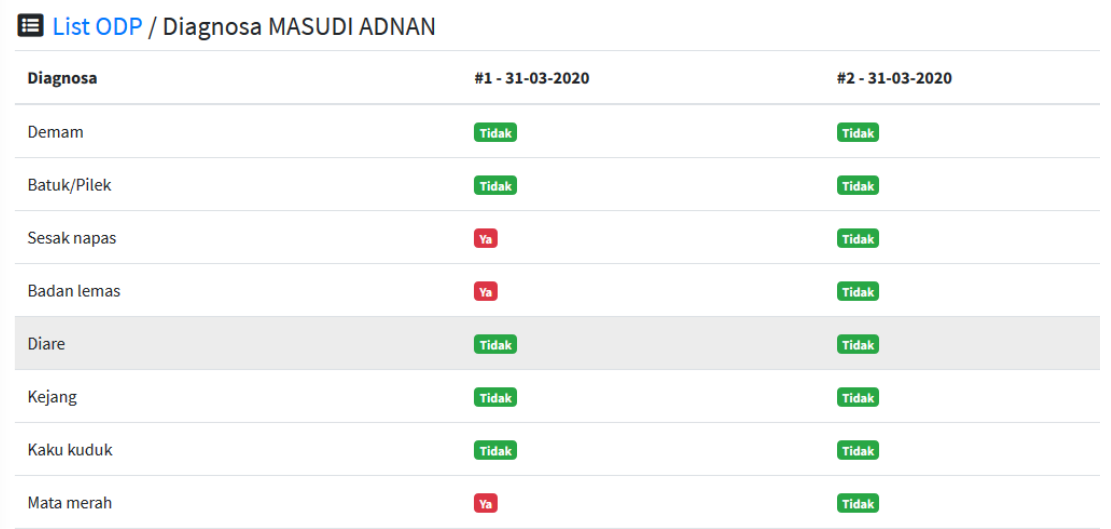

Gambar 11 Tampilan diagnosa Kesehatan ODP

Pada tampilan daftar ODP apabila petugas mengklik icon ipada kolom info travel, maka akan menampilkan histori perjalanan yang telah dilakukan odp dengan tampilan seperti Gambar.12.

\begin{tabular}{lcc}
\hline 国 List ODP / History Perjalanan HAFIDZ ADNAN & \\
\hline & $\# 1$ & $\# 2$ \\
\hline Kota & BANDUNG & BANDUNG \\
\hline Tanggal Keberangkatan & $29-03-2020$ & $20-03-2020$ \\
\hline Tanggal Kedatangan & $29-03-2020$ & $19-03-2020$ \\
\hline
\end{tabular}

Gambar.12 Tampilan histori perjalanan ODP

Pada tampilan daftar ODP apabila petugas mengklik icon 1 pada kolom info tracking, maka petugas akan dapat melihat informasi perpindahan lokasi yang dilakukan oleh ODP selama masa karantina dan melihat lokasinya di peta sehingga dapat memberikan peringatan atau himbauan kepada odp tersebut sebagaimana ditunjukkan pada Gambar.13.

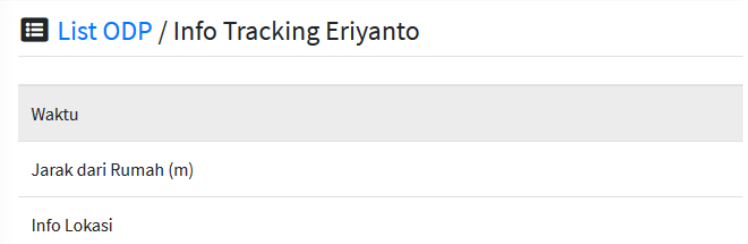

Gambar.13 Tampilan histori tracking ODP

CAsosiasi Prakarsa Indonesia Cerdas (APIC) - 2020 
Selanjutnya Pada tampilan daftar ODP apabila petugas mengklik icon $\mathbb{~}$ petugas akan dapat melakukan perubahan status pada odp tersebut. Menu ini hanya akan tampil pada level user faskes sebagaimana ditunjukkan Gambar.14.

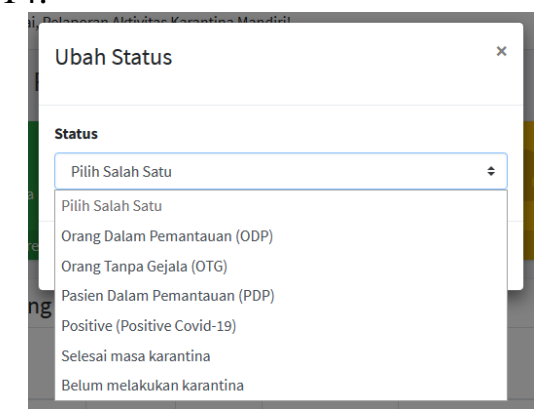

Gambar.14 Pengelolaan Profil Fasilitas Kesehatan (Puskesmas)

Menu ini menampilkan informasi umum dari pengguna yang melakukan login dan memperbaharui password masing-masing pengguna sebagaimana Gambar.15.

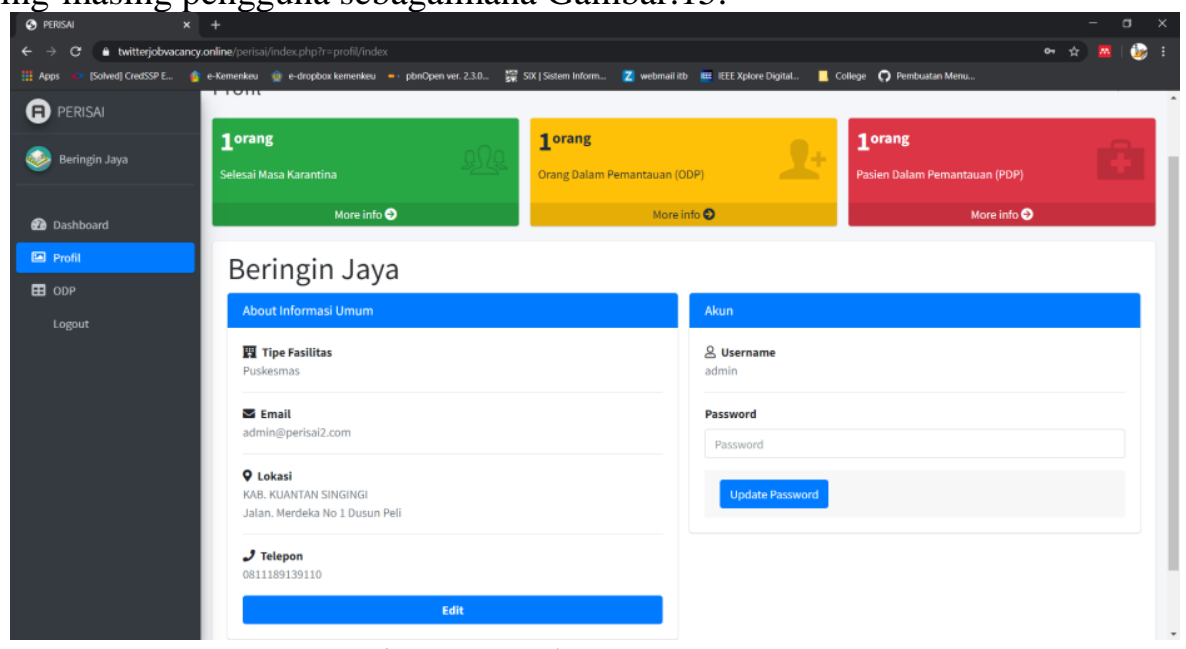

Gambar.15 Tampilan pengaturan pengguna

\section{PERISAI API}

API yang dikembangkan dalam PERISAI menggunakan Lumen yang merupakan Micro Framework dari pengembang Laravel untuk mengakomodasi kebutuhan developer yang ingin membuat aplikasi dalam skala lebih kecil. Karena banyak library yang dihilangkan dalam bundle source code, Lumen dapat dijadikan sebuah framework untuk membuat REST API. Ada beberapa Micro Framework lain yang dikhususkan untuk membuat REST API pada PHP seperti Slim Framework, Silex, dsb dengan keistimewaanya masing-masing, namun yang menarik adalah Lumen mampu menghandle hingga 1900 request per second, perbedaan lain yaitu Lumen menggunakan PHP versi ke 7 sebagai syarat penggunaannya, sedangkan Slim masih bisa digunakan PHP versi 5 ke atas [12].

Metode pengamanan yang digunakan pada API PERISAI adalah JSON Web Token. JSON Web Token (JWT) yang dirilis oleh IETFuntuk mengamankan komunikasi API dengan metode autentikasi digital signature menggunakan HMAC dengan SHA256 [13]. Dengan demikian end point API tidak dapat diakses tanpa bearer token yang valid dan token tersebut dapat di decrypt untuk mendapatkan informasi user yang login atau yang menggunakan end point API. Selain itu, API PERISAI didokumentasikan menggunakan Swagger. Swagger merupakan tools yang membantu membuat dokumentasi API menjadi lebih readable dan painless [14]. Dengan menggunakan swagger, dokumentasi API akan lebih mudah dibaca oleh developer sehingga pihak lain dapat dengan mudah mengimplementasikan API tersebut. Sedangkan arsitektur API PERISAI dapat dilihat pada Gambar.16.

CAsosiasi Prakarsa Indonesia Cerdas (APIC) - 2020 


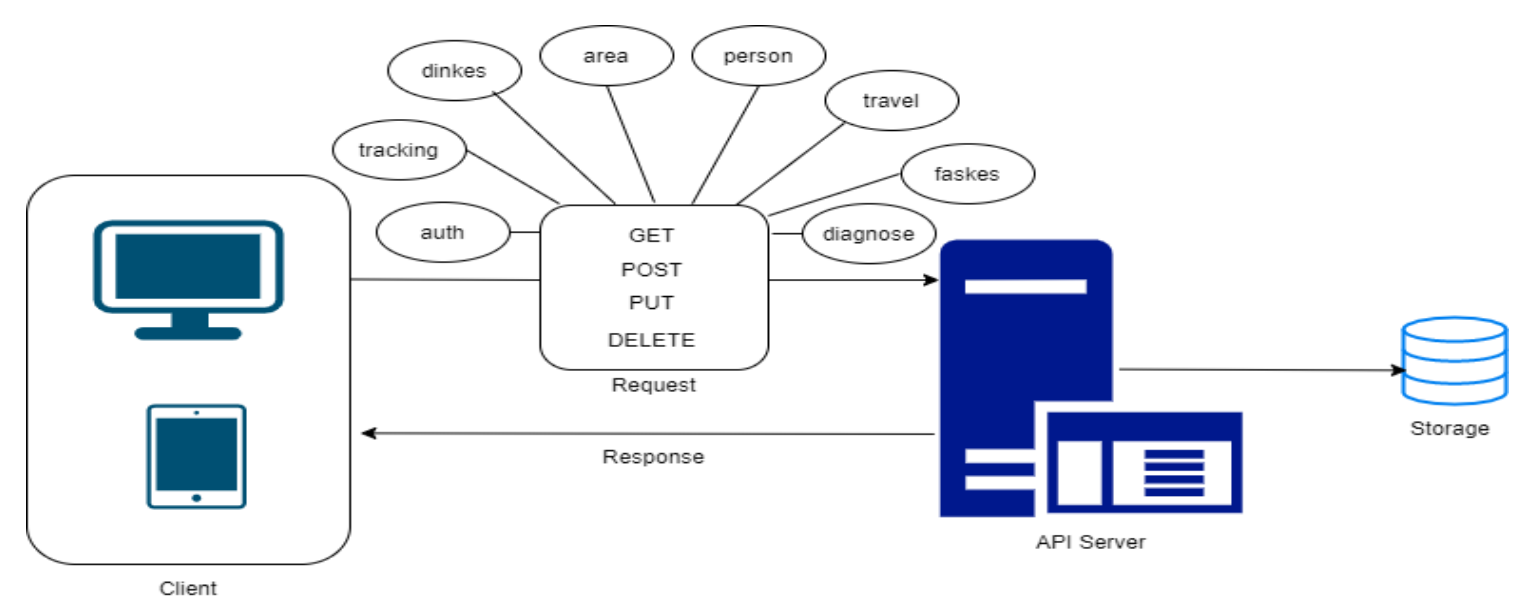

Gambar.16 Arsitektur API PERISAI

\section{KESIMPULAN}

Hasil dari penelitian ini menunjukkan bahwa teknologi dapat mendukung proses transformasi digital layanan pemerintah untuk melakukan protokol kesehatan terhadap ODP yang dimulai dari digitisasi Kartu Kewaspadaan Kesehatan yang dikeluarkan oleh Kementerian Kesehatan. Selanjutnya, digitisasi tersebut berubah menjadi sebuah inovasi sistem yang menawarkan value baru dalam kasus ini memantau proses isolasi mandiri ODP yang baru datang dari wilayah terjangkit virus COVID-19. Sistem Informasi PERISAI diharapkan juga menjadi salah satu teknologi persuasif yang dapat meng-engage komitmen ODP dalam melakukan isolasi mandiri. Namun, penggunaan PERISAI secara masif perlu didukung pemerintah sebagai institusi yang menegaskan bahwa aplikasi PERISAI wajib digunakan oleh ODP dan menjamin bahwa data privasi yang dikumpulkan tidak akan digunakan untuk kepentingan pihak ketiga. Dalam pengembangan selanjutnya, kapabilitas modul aplikasi web dapat dioptimalkan dengan menerapkan algoritma machine learning sehingga justifikasi status ODP setelah masa isolasi selesai dapat dilakukan secara otomatis dengan parameter yang telah ditentukan. Selain itu, web service yang disediakan oleh PERISAI berperan sebagai jembatan untuk memudahkan integrasi dengan sistem lainnya. Sehingga, PERISAI diharapkan dapat mendukung penyajian informasi secara holistik dalam rangka mendukung penanganan COVID-19 di Indonesia pada umumnya dan Kabupaten/Kota pada khususnya.

\section{ACKNOWLEDGEMENT}

Penelitian ini dilakukan sebagai kontribusi mahasiswa magister layanan teknologi informasi yang didukung oleh SCCIC (Smart City and Community Innovation Center) dan APICS (Asosiasi Prakarsa Indonesia Cerdas) dalam rangka membantu penanggulangan wabah COVID-19 di Indonesia yang dilakukan oleh Dinas Kesehatan dan lembaga pemerintah terkait melalui pemanfaatan Teknologi Informasi dan Komunikasi.

\section{REFERENSI}

[1] Centers for Disease Control and Prevention (CDC), "Coronavirus Disease 2019 (COVID-19)". 15 February 2020. Archived from the original on 26 February 2020. Retrieved 20 February 2020.

[2] Kementerian Kesehatan, Pedoman Pencegah. Dan Pengendali. CORONAVIRUS Dis., 2020.

[3] M. Güler and G. Büyüközkan, "ScienceDirect Analysis of Digital Transformation Strategies with an Integrated Fuzzy AHP- Axiomatic Design Methodology Analysis of Digital

[4] Transformation Strategies with Integrated Fuzzy Analysis of Digital Transformation Strategies

CAsosiasi Prakarsa Indonesia Cerdas (APIC) - 2020 
with Integrated Fuzzy," IFAC Pap., vol. 52, no. 13, pp. 1186-1191, 2019

[5] T. Almarabeh, Y. K. Majdalawi, and H. Mohammad, Cloud Computing of E-Government, Commun. Netw, no. January 2016, 2016.

M. D. Lytras, and A. C. Serban, "E-Government Insights to Smart Cities Research: European

Union (EU) Study and the Role of Regulations", IEEE Access ( Volume: 8 ), pp. 65313 65326, 2020.

[6] A. Bouza, API Product Management, Medium, 23 March 2018. [Online].

[7] Available: https://medium.com/api-product-management/what-is-digital-transformationdigitalization-and-digitization-c76277ffbdd6. [Accessed 1205 2020].

[8] B.J. Fogg, Introduction Persuasion in the Digital Age. Stanford University, 2003.

Sibero, Alexander F.K. 2011. "Kitab Suci Web Programming”. Yogyakarta:Simarmata (2010:10)

[9] Doğan, S., Betin-Can, A., and Garousi, V. (2014): Web application testing: A systematic literature review, Journal of Systems and Software, 91(1), 174-201.

[10] X. Kong, S. Member, X. Liu, B. Jedari, and M. Li, "Mobile Crowdsourcing in Smart Cities : Technologies, Applications, and Future Challenges," IEEE Internet Things J., vol. 6, no. 5, pp. 8095-8113, 2019.

[11] P. Roger S Pressman, Software Engineering: A Practitioner's Approach, Seventh Edition, 7th ed. New York: McGraw-Hill, 2010.

[12] Stauffer, Matt. Laravel: Up \& Running: A Framework for Building Modern PHP Apps. O'Reilly Media, 2019.

[13] Jones, M., J. Bradley, and N. Sakimura. "Rfc 7519: Json web token (jwt)." IETF. May (2015).

[14] De, Brajesh. "API documentation." In API Management, pp. 59-80. Apress, Berkeley, CA, 2017. 